\title{
Structural and Chemical Attributes of Soil Inorganic Fractions for Environmental Characterization in the Brazilian Semiarid Region
}

\author{
Thais Cristina de Souza Lopes ${ }^{1}$, Jeane Cruz Portela ${ }^{1}$, Stefeson Bezerra de Melo ${ }^{1}$, Thamirys Duarte Ávila ${ }^{1}$, \\ Francisco Wellington Andrade da Silva ${ }^{1}$, Joseane Dunga da $\operatorname{Costa}^{1} \&$ Aldi Nestor de Souza Júnior ${ }^{2}$ \\ ${ }^{1}$ Universidade Federal Rural do Semi-Árido, Mossoró, Brazil \\ ${ }^{2}$ Instituto Federal do Maranhão, Grajaú, Brazil \\ Correspondence: Jeane Cruz Portela, Universidade Federal Rural do Semi-Árido, Av. Francisco Mota, 572, \\ Bairro Costa e Silva, CEP: 59.625-900, Mossoró, RN, Brazil. Tel: 55-840-996-933-669. E-mail: \\ jeaneportela@ufersa.edu.br
}

Received: September 11, 2018

Accepted: November 3, 2018

Online Published: December 15, 2018

doi:10.5539/jas.v11n1p527

URL: https://doi.org/10.5539/jas.v11n1p527

\begin{abstract}
Soil structure affects plant growth factors in agroecosystems. The relationships of these factors with soil texture and chemical attributes are important to differentiate environments. The objective of this work was to evaluate the relationship of soil structural attributes with physical and chemical attributes of different soils to differentiate environments, using multivariate statistics. The research was carried out in the Terra da Esperança Settlement Project, in Governador Dix-Sept Rosado, RN, semiarid region of Brazil. Ten soil profiles were evaluated: Haplustepts in a conventional area (1CA); Haplustepts in a collective area with (2CA); Haplustepts in an agroecological area with native forest (3AGRO); Eutrustox in a native forest (4NF); Calciustolls in a conventional area of pasture (5CAP); Haplustepts in a native forest (6NF); Haplustepts in an native forest (7NF); Usticfluvents in a permanent conservation area with Licania rigida (8PPA); Haplustepts in a native forest (9MN); and Haplustepts in a collective area with Spondias spp. (10SP). Ten soil samples were collected and analyzed by horizons in volumetric rings and in soil blocks (aggregate analysis), with three replications. Structural, physical, and chemical attributes were evaluated. The data were subjected to multivariate statistical analysis, using correlation matrix, cluster analysis, and factorial analysis considering the factors as principal components. According to the factorial analysis, Factor 1 (F1) and Factor 2 (F2)-F1 consisting of clay, $\mathrm{Ca}^{2+}, \mathrm{Na}^{+}$, sum of bases, and base saturation (V), and F2 consisting of cation exchange capacity (CEC), total organic carbon, macroporosity, particle density, $\mathrm{K}^{+}$, and microporosity-were essential to differentiate the environments. The cluster analysis formed four groups. The structural groups showed greater similarity, denoting the relationship between source material and land use, followed by the chemical groups $\mathrm{P}, \mathrm{K}^{+}, \mathrm{CEC}, \mathrm{Ca}^{2+}, \mathrm{V}$, and $\mathrm{pH}$ for the Calciustolls; the structural weighted mean diameter, geometric mean diameter, soil aggregates larger than $2 \mathrm{~mm}$, plasticity index, and plasticity limit for the Eutrustox; and the physical and chemical attributes EC, $\mathrm{Na}^{+}, \mathrm{Silt}$, macroporosity, total calculated porosity, aluminum saturation, total sand, volumetric moisture, $\mathrm{Mg}^{2+}$ and particle density for the Haplustepts and the Usticfluvents. The clay fraction presented correlation with chemical attributes (F1) for the distinction of soil classes and land uses. The soil classes presented eutrophic character $(\mathrm{V} \geq 50 \%)$ as a function of the $\mathrm{Na}^{+}$and $\mathrm{Ca}^{2+}$ contents, including the Eutrustox (4NF), despite its lower contents when compared to the other soil classes. This is a local peculiarity due to the climatic pattern of the Brazilian semiarid region.
\end{abstract}

Keywords: caatinga, multivariate analysis, aeration

\section{Introduction}

The Brazilian semiarid region is a diverse environment regarding geological formation, relief, and vegetation and presents local peculiarities and landscapes. This directly affects the pedology and soil morphology of this region, generating classes of soils characterized by spatial and temporal variability of morphological, physical, chemical, and mineralogical attributes (Carvalho, 2017). Most part of these soils are pedogenetically characterized as poorly developed, presenting physical limitations for development of plants; however, these soils present, in general, good fertility due to their lithology and the climatic pattern of the region, combined with other factors, and soil formation processes. 
However, despite the soil attributes in this region, concise information of the natural resources and their potentialities and limitations, considering intrinsic characteristics, the environment, and local people is needed for a conscious use of these resources; this can subsidize the implementation of activities, considering the potential of the local physical environment, and land uses to meet production purposes, and ensure soil conservation (Lepesh, 2015).

The structural arrangement of the soil particles can be modified by human actions. It is connected to plant growth, which affects porous space, flows of air, water, and heat to plant roots, nutrient supply, development of the root system, and soil mechanical resistance to penetration, which are important factors for to the development of agricultural crops (Machado \& Mielniczuk, 2009).

Thus, characterizing the structural and chemical attributes of the soil and their correlations is necessary to subsidize decision making to improve and maintain the soil productive capacity, considering its potentialities and limitations.

According to Castilho (2017), multivariate analysis has been used successfully in studies involving soil attributes to identify and distinguish environments and know the most sensitive attributes for their distinguishing, considering simultaneously several characteristics, and correlations between them.

In this context, the objective of this work was to evaluate the relationship of soil structural attributes with physical and chemical attributes of different soils to differentiate environments in the Terra da Esperança Settlement Project, in the western mesoregion of the state of Rio Grande do Norte, Brazil, using multivariate analysis.

\section{Materials and Methods}

The research was developed in the Terra da Esperança Settlement Project, in the municipality of Governador Dix Sept Rosado $\left(05^{\circ} 27^{\prime} 32^{\prime \prime} \mathrm{S}\right.$ and $\left.37^{\circ} 31^{\prime} 15.6^{\prime \prime} \mathrm{W}\right)$, which is in the Chapada do Apodi microregion, western mesoregion of the state of Rio Grande do Norte, semiarid region of Brazil. The climate of the region is hot semiarid (BSw'h), according to the Köpper classification, with annual average precipitation of $712 \mathrm{~mm}$ from February to May (Alvares et al., 2013). The native vegetation of the region is hyper-xerophilic Caatinga.

This study considered different preserved agroecosystems (reference areas), agricultural areas, and different soil classes and horizons. Ten soil profiles were evaluated: Haplustepts in a conventional area (1CA) $\left(05^{\circ} 29^{\prime} 13.0^{\prime \prime} \mathrm{S}\right.$; $\left.37^{\circ} 24^{\prime} 33.1^{\prime \prime} \mathrm{W}\right)$; Haplustepts in a collective area (2CA) $\left(05^{\circ} 30^{\prime} 17.6^{\prime \prime} \mathrm{S} ; 37^{\circ} 27^{\prime} 01.3^{\prime \prime} \mathrm{W}\right)$; Haplustepts in an agroecological area with native forest (3AGRO) $\left(05^{\circ} 30^{\prime} 22.9^{\prime \prime} \mathrm{S} ; 37^{\circ} 27^{\prime} 06.8^{\prime \prime} \mathrm{W}\right)$; Eutrustox in a native forest (4NF) $\left(05^{\circ} 29^{\prime} 42.7^{\prime \prime} \mathrm{S} ; 3^{\circ} 28^{\prime} 30.3^{\prime \prime} \mathrm{W}\right)$; Calciustolls in a conventional area of pasture (5CAP) (05 $32^{\prime} 21.18^{\prime \prime} \mathrm{S}$; $\left.37^{\circ} 26^{\prime} 01.2^{\prime \prime} \mathrm{W}\right)$; Haplustepts in a native forest (6NF) $\left(05^{\circ} 32^{\prime} 24.0^{\prime \prime} \mathrm{S}\right.$; $\left.37^{\circ} 25^{\prime} 59.4^{\prime \prime} \mathrm{W}\right)$; Haplustepts in an native forest (7NF) $\left(05^{\circ} 28^{\prime} 40.7^{\prime \prime} \mathrm{S} ; 37^{\circ} 26^{\prime} 16.3^{\prime \prime} \mathrm{W}\right)$; Usticfluvents in a permanent conservation area with Licania rigida (8PPA) $\left(05^{\circ} 29^{\prime} 45.5^{\prime \prime} \mathrm{S} ; 37^{\circ} 27^{\prime} 50.6^{\prime \prime} \mathrm{W}\right)$; Haplustepts in a native forest (9NF) (05 $\left.28^{\prime} 54.7^{\prime \prime} \mathrm{S} 37^{\circ} 24^{\prime} 52.7^{\prime \prime} \mathrm{W}\right)$; and Haplustepts in a collective area with Spondias spp. (10SP) $\left(05^{\circ} 29^{\prime} 50.9^{\prime \prime} \mathrm{S} ; 37^{\circ} 27^{\prime} 14.8^{\prime \prime} \mathrm{W}\right)$.

The environments were characterized by sampling deformed and undisturbed soil samples in different horizons. They were placed in plastic bags and analyzed in the Laboratory of Soil, Water, and Plant Analyses of the Center for Agrarian Sciences of the Federal Rural University of the Semi-arid Region (LASAP-CCA-UFERSA), following the methodology proposed by Teixeira et al. (2017).

The variables evaluated were related to: inorganic fractions - texture (silt, sand, and clay), and particle density (Dp); consistency limits-liquidity limit (LL), plasticity limit (PL), and plasticity index (PI); soil structural attributes - density, macroporosity, microporosity, total porosity (TP), and volumetric moisture; and aggregate stability - weighted mean diameter (WMD), and geometric mean diameter (GMD). The chemical attributes evaluated were: electrical conductivity (EC), $\mathrm{pH}$ in water, total organic carbon (TOC), phosphorus (P), potassium $\left(\mathrm{K}^{+}\right)$, calcium $\left(\mathrm{Ca}^{2+}\right)$, magnesium $\left(\mathrm{Mg}^{2+}\right)$, cation exchange capacity $(\mathrm{CEC})$, base saturation $(\mathrm{V})$ and aluminum saturation $(\mathrm{m})$.

The granulometry was obtained by the pipette method using chemical dispersant (sodium hexametaphosphate) and distilled water in $20 \mathrm{~g}$ of the air-dried fine earth, with slow mechanical agitation (Wagner $50 \mathrm{rpm}$ ) for 16 hours. The sand fraction $(2$ to $0.05 \mathrm{~mm})$ was quantified by sieving, clay $(<0.002 \mathrm{~mm})$ by sedimentation, and silt $(0.05$ to $0.002 \mathrm{~mm})$ by the difference between the total sand and clay fractions. Particle density analysis was carried out using the volumetric flask method described by Kiehl (1979), oven-dried fine earth at $105{ }^{\circ} \mathrm{C}$, and ethyl alcohol. The soil consistency tests were evaluated based on LL, with the use of the Casagrande device.

PL was evaluated with four replications, using a representative sample of the central part of the shear of the soil in the metallic sphere of the equipment from the determination of the liquidity limit, which formed a compressed 
sphere on a glass plate, resulting in a cylindrical rod of 3.0 to $4.0 \mathrm{~mm}$ in diameter without breaking or flowing. PI was evaluated by the difference between LL and PL. Gravimetric moisture was evaluated in the plasticity condition for the soil rods.

Undisturbed samples were collected using Uhland type device, and rings with height of $0.05 \mathrm{~m}$ and diameter of $0.05 \mathrm{~m}$. Ten samples were collected per horizon in the soil profiles. Soil density, macroporosity, microporosity, and total porosity were evaluated. Soil density was evaluated using a volumetric ring with known volume, as described by Forsythe (1975), with averages represented by the quotient between the soil solid particle weight and the total volume of the soil, and expressed in $\mathrm{kg} \mathrm{dm}^{-3}$.

Macroporosity, microporosity, and total porosity were evaluated using undeformed samples in volumetric rings; they were saturated for 48 hours and weighed (total porosity). The tension table method was used, according to Kiehl (1979), considering $6 \mathrm{kPa}$ stress (microporosity), with the total soil porosity (Pt) evaluated by measuring the soil moisture saturation according to equation: $\mathrm{Pt}=[(\mathrm{Msat}-\mathrm{Ms}) / \mathrm{VT}] \times 100$, wherein MSat is the saturated soil weight; Ms is the dried soil weight; and VT is the sample volume. Microporosity was evaluated by the water volume retained in the soil for the $\mathrm{h}$ value equal to $60 \mathrm{~cm}$ of water (pore radius of approximately $25 \mu \mathrm{m}$ ). Soil macroporosity was evaluated by the difference between total porosity and microporosity.

Soil blocks from the horizons of each soil class were sampled and sieved in $4.0 \mathrm{~mm}$ and $2.0 \mathrm{~mm}$ mesh sieves, preserving the aggregate structure for the study of the aggregates, using units of weakness. The wet sieve method, with mesh sieves of $4.76,2.00,1.00,0.50$, and $0.25 \mathrm{~mm}$ and a vertical oscillation device with 42 oscillations per minute, was used according to Kemper and Rosenau (1986). The soil aggregates were separated by shaking in water, and the samples were dried in an oven at $105^{\circ} \mathrm{C}$; the sand fraction was discarded, and the aggregate size distribution, percentage of aggregation, and stable aggregates in water, weighted mean diameter (WMD), and geometric mean diameter (GMD) were evaluated.

Deformed samples were used for the chemical analyses. The attributes evaluated were $\mathrm{pH}$ in water, electrical conductivity (EC) in water, TOC by digestion of organic matter, and macronutrients - exchangeable calcium $\left(\mathrm{Ca}^{2+}\right)$ and exchangeable magnesium $\left(\mathrm{Mg}^{2+}\right)$ using potassium chloride as extractant, and phosphorus $(\mathrm{P})$, sodium $\left(\mathrm{Na}^{+}\right)$and potassium $\left(\mathrm{K}^{+}\right)$using Mehlich 1. Subsequently, the cation exchange capacity (CEC) and base saturation (V) were evaluated and interpreted according to the Manual of Recommendations for Use of Correctives and Fertilizers of Minas Gerais (Ribeiro \& Guimarães, 1999).

The structure attributes of the deformed samples were evaluated with four replications; they were subjected to statistical analysis, using multivariate analysis to identify the more sensitive attributes for differentiating the environments, considering the different land uses, using the Statistica 7.0 program (Stansoft, 2004).

The analytical results from the correlation matrix and multivariate analysis were based on cluster analysis (CA), factorial analysis (FA) and principal component analysis (PCA). The CA was represented by a dendrogram of the distance matrix, using the Euclidean distance to measure similarity, and the Ward's method to connect the cases. The importance of each variable in the CA for differentiating the environments was measured as a function of its smaller distance from the reference axis, $\mathrm{x}$ or $\mathrm{y}$, and the axis that contains the largest value of accumulated variance that explains most of the causes of variance (Sá Paye et al., 2012).

The established connecting distance in the dendrogram from the cluster analysis was 12 , which formed four large groups of soils (Figure 1). The FA showed the contribution of each variable to each factor; the factors were defined by differentiating the attributes of the environments. The environments were distinguished using six diagrams of the principal components (Factors 1 and 2, Factors 3 and 4, and Factors 5 and 6) considering physical and chemical attributes. These data were used to create two-dimensional diagrams to distinguish areas and vector projection diagrams to identify sensitive soil attributes for differentiating the environments (Hair et al., 2009).

\section{Results and Discussion}

Significant correlations were found mainly between the weighted mean diameter (WMD), characteristics of soil aggregates larger than $2 \mathrm{~mm}(\mathrm{AGR}>2 \mathrm{~mm})$, liquidity limit (LL), plasticity index (PI), total porosity determined (TPd), total porosity calculated (PTc), microporosity, total sand (TS), clay, base saturation (V), and aluminum saturation (Als) (Table 1).

The $\mathrm{pH}$ of the samples presented significant correlations with electrical conductivity (EC), $\mathrm{Ca}^{2+}, \mathrm{V}$, and Als. These correlations are explained by the soil classes, geological formation of the study region, and pedogenetic processes. Thus, the high correlations between $\mathrm{pH}$ and $\mathrm{EC}, \mathrm{Ca}^{2+}$, and $\mathrm{V}$ denoted the effect of these variables on the high alkalinity levels found, especially in the Calciustolls. EC represents the amount of soluble salts in the 
exchange complex and is direct proportional to the number of ions; high amount of exchangeable bases increases soil alkalinity, which hinders the development of crops (Ribeiro et al., 2007).

$\mathrm{Ca}^{2+}$ was significant due to the local lithology. According to Angelim et al. (2006), the Chapada do Apodi region is in the Jandaíra geological formation, constituted basically of limestone, which is rich in carbonate rocks that provide high amounts of calcium and magnesium that contribute to the soil alkalinity. Mota et al. (2008) characterized soils of the Chapada do Apodi and found effects of its lithology on the $\mathrm{pH}$, denoting that soils from limestones have neutral to alkaline $\mathrm{pH}$ because of their high carbonate contents, which affects exchangeable bases, as also observed by Marinho et al. (2016).

The $\mathrm{pH}$ and Als presented correlation because aluminum is soluble in a wide $\mathrm{pH}$ range; Als represents the proportion of soluble aluminum to exchangeable bases and aluminum in the CEC of the soil. These variables are inversely proportional, with a lowest critical $\mathrm{pH}$ value of 5.5 for $\mathrm{Al}^{3+}$ becoming more soluble, generating loss of exchangeable bases and silica by leaching, predominating the $\mathrm{pH}$ generated by the $\mathrm{Al}^{3+}$ and $\mathrm{H}+\mathrm{Al}$ released from the rocks to the soil solution (Perin et al., 2010) due to the latolization process, typical in Eutrustox soils.

TOC showed significant correlations with $\mathrm{P}, \mathrm{K}^{+}, \mathrm{Ca}^{2+}$, and CEC, contributing to differentiate Group IV (Table 1, and Figure 1), characterized by the Calciustolls. These correlations are explained by the contribution of TOC to these nutrients. Moreover, $\mathrm{K}^{+}$is not metabolized by plants but incorporated into the plant biomass, forming connections with organic complexes of easy reversibility and, consequently, rapid release rate by plant residues (Perin et al., 2010).

The high correlation between $\mathrm{P}$ and SOM is due to the cycling of this nutrient in the soil by microbial activity due to the plant energy support, in the labile and non-labile forms, especially in surface horizons, with accentuated effect in areas of native forest due to constant deposition of plant residues (Turrion et al., 2010). The contribution of TOC to $\mathrm{P}$ release is more significant in weathered soils in tropical regions, where 1:1 clay minerals of low colloidal activity present high adsorption force, favoring complexation of organic and inorganic forms of $\mathrm{P}$ in the soil matrix, making this element little labile, resulting in low fertility (Machado et al., 2012). Thus, organic P affects the availability of this element in the soil. Pereira et al. (2011) evaluated light SOM and remaining $\mathrm{P}$ for agriculture purposes and found increased light SOM content in areas under no-tillage system with cover plants, and reduced adsorption of $\mathrm{P}$ because of the adsorbed SOM, or blocked adsorption sites that occur on the surface of clays with low colloidal activity. Leite et al. (2017) reported the contribution of SOM to labile organic $\mathrm{P}$ in the soil; the maintenance of plant cover on the area of cultivation (unburned sugarcane plants) generated higher organic $\mathrm{P}$ contents and other forms of $\mathrm{P}$ (total $\mathrm{P}$, available $\mathrm{P}$, inorganic $\mathrm{P}$, and $\mathrm{P}$ in humic substances) when compared to the areas with burned sugarcane plants. 
Table 1. Correlation matrix for soil attributes in the study areas. Terra da Esperança Settlement Project, Governador Dix-Sept Rosado, Rio Grande do Norte, Brazil

\begin{tabular}{|c|c|c|c|c|c|c|c|c|c|c|c|c|c|c|c|c|c|c|c|c|c|c|c|c|c|c|}
\hline & WMD & GMF & AGR $>2 \mathrm{~mm}$ & LL & PL & PI & TPd & TPc & Microp. & Macrop. & TS & Silt & Clay & Dp & $\theta$ & $\mathrm{pH}$ & EC & TOC & $\mathbf{P}$ & $\mathbf{K}^{+}$ & $\mathrm{Na}^{+}$ & $\mathrm{Ca}^{2+}$ & $\mathrm{Mg}^{2+}$ & CEC & $\mathbf{V}$ & $\mathbf{A l}_{\mathrm{s}}$ \\
\hline WMD & 1.00 & & & & & & & & & & & & & & & & & & & & & & & & & \\
\hline GMF & 0.26 & 1.00 & & & & & & & & & & & & & & & & & & & & & & & & \\
\hline $\mathrm{AGR}>\mathbf{2 m m}$ & 0.44 & 0.05 & 1.00 & & & & & & & & & & & & & & & & & & & & & & & \\
\hline LL & 0.42 & 0.16 & 0.42 & 1.00 & & & & & & & & & & & & & & & & & & & & & & \\
\hline PL & 0.20 & 0.07 & 0.54 & 0.69 & 1.00 & & & & & & & & & & & & & & & & & & & & & \\
\hline PI & 0.42 & 0.16 & 0.14 & 0.82 & 0.15 & 1.00 & & & & & & & & & & & & & & & & & & & & \\
\hline TPd & 0.57 & -0.11 & 0.43 & 0.34 & 0.03 & 0.44 & 1.00 & & & & & & & & & & & & & & & & & & & \\
\hline TPc & 0.33 & 0.07 & 0.31 & 0.18 & 0.14 & 0.13 & 0.61 & 1.00 & & & & & & & & & & & & & & & & & & \\
\hline Microp. & 0.66 & -0.12 & 0.46 & 0.46 & 0.15 & 0.50 & 0.93 & 0.52 & 1.00 & & & & & & & & & & & & & & & & & \\
\hline Macrop. & -0.04 & -0.02 & 0.06 & -0.18 & -0.28 & -0.02 & 0.46 & 0.37 & 0.10 & 1.00 & & & & & & & & & & & & & & & & \\
\hline TS & -0.46 & 0.10 & -0.28 & -0.37 & -0.15 & -0.39 & -0.58 & -0.31 & -0.49 & -0.39 & 1.00 & & & & & & & & & & & & & & & \\
\hline Silt & 0.14 & 0.05 & 0.05 & 0.03 & 0.04 & 0.00 & 0.13 & 0.17 & -0.02 & 0.39 & -0.74 & 1.00 & & & & & & & & & & & & & & \\
\hline Clay & 0.43 & -0.21 & 0.31 & 0.47 & 0.15 & 0.52 & 0.62 & 0.20 & 0.69 & 0.00 & -0.33 & -0.39 & 1.00 & & & & & & & & & & & & & \\
\hline Dp & -0.09 & 0.13 & -0.18 & -0.03 & 0.02 & -0.06 & -0.46 & -0.06 & -0.44 & -0.19 & 0.15 & 0.09 & -034 & 1.00 & & & & & & & & & & & & \\
\hline$\theta$ & 0.03 & 0.02 & -0.14 & -0.11 & 0.02 & -0.17 & -0.30 & -0.09 & -0.24 & -0.24 & 0.19 & -0.08 & -0.14 & 0.26 & 1.00 & & & & & & & & & & & \\
\hline pH & 0.19 & -0.07 & 0.25 & -0.08 & 0.07 & -0.17 & 0.19 & 0.08 & 0.16 & 0.13 & -0.42 & 0.49 & -0.11 & 0.20 & 0.03 & 1.00 & & & & & & & & & & \\
\hline EC & 0.06 & -0.06 & 0.07 & 0.22 & 0.17 & 0.17 & 0.14 & 0.29 & 0.07 & 0.22 & -0.52 & 0.62 & -0.15 & 0.21 & -0.07 & 0.35 & 1.00 & & & & & & & & & \\
\hline TOC & 0.10 & 0.03 & 0.06 & 0.02 & 0.08 & -0.03 & 0.06 & 0.14 & 0.20 & -0.32 & 0.18 & -0.07 & -0.14 & -0.15 & 0.07 & 0.22 & -0.02 & 1.00 & & & & & & & & \\
\hline $\mathbf{P}$ & 0.12 & -0.05 & 0.32 & 0.29 & 0.26 & 0.20 & 0.12 & 0.24 & 0.17 & -0.08 & 0.00 & 0.03 & -0.05 & 0.20 & -0.05 & 0.15 & 0.17 & 0.56 & 1.00 & & & & & & & \\
\hline $\mathbf{K}^{+}$ & 0.18 & -0.03 & 0.10 & 0.00 & 0.18 & -0.13 & 0.02 & 0.21 & 0.18 & -0.38 & 0.21 & -0.26 & 0.07 & 0.08 & 0.19 & 0.17 & 0.04 & 0.66 & 0.31 & 1.00 & & & & & & \\
\hline $\mathrm{Na}^{+}$ & -0.11 & 0.03 & -0.03 & 0.08 & -0.01 & 0.11 & 0.06 & 0.14 & -0.10 & 0.40 & -0.54 & 0.72 & -0.28 & 0.13 & -0.05 & 0.30 & 0.67 & -0.19 & 0.00 & -0.27 & 1.00 & & & & & \\
\hline $\mathrm{Ca}^{2+}$ & 0.29 & -0.03 & 0.18 & 0.03 & -0.09 & 0.10 & 0.55 & 0.13 & 0.52 & 0.24 & -0.17 & -0.10 & 0.37 & -0.32 & 0.00 & 0.47 & -0.15 & 0.36 & 0.21 & 0.14 & -0.14 & 1.00 & & & & \\
\hline $\mathbf{M g}^{2+}$ & -0.18 & 0.00 & -0.17 & -0.20 & -0.17 & -0.13 & -0.32 & -0.03 & -0.47 & 0.26 & -0.14 & 0.46 & -0.46 & 0.36 & 0.13 & -0.09 & 0.31 & -0.18 & 0.19 & -0.20 & 0.53 & -0.39 & 1.00 & & & \\
\hline CEC & 0.16 & -0.06 & 0.01 & -0.09 & -0.22 & 0.05 & 0.36 & 0.14 & 0.24 & 0.38 & -0.22 & 0.14 & 0.10 & -0.14 & 0.08 & 0.33 & 0.06 & 0.34 & 0.36 & 0.12 & 0.20 & 0.77 & 0.25 & 1.00 & & \\
\hline V & 0.38 & 0.02 & 0.45 & 0.10 & 0.20 & -0.02 & 0.43 & 0.20 & 0.44 & 0.10 & -0.43 & 0.27 & 0.20 & 0.06 & 0.07 & 0.87 & 0.21 & 0.21 & 0.14 & 0.25 & 0.14 & 0.61 & -0.30 & 0.33 & 1.00 & \\
\hline $\mathbf{A I _ { s }}$ & -0.35 & -0.09 & -0.36 & -0.06 & -0.16 & 0.05 & -0.41 & -0.23 & -0.43 & -0.08 & 0.25 & -0.20 & -0.06 & -0.01 & -0.05 & -0.70 & -0.15 & -0.19 & -0.08 & -0.18 & -0.10 & -0.50 & 0.28 & -0.23 & -0.87 & 1.00 \\
\hline
\end{tabular}

Note. WMD = weighted mean diameter; GMD = geometric mean diameter; AGR $>2 \mathrm{~mm}=$ soil aggregates larger than $2 \mathrm{~mm}$; LL = liquidity limit; PL = plasticity limit; PI = plasticity index; TPd = total porosity determined; TPc $=$ total porosity calculated; Microp = microporosity; Macrop $=$ macroporosity; $\mathrm{TS}=$ total sand; Dp $=$ particle density; $\theta=$ volumetric moisture; $\mathrm{EC}=$ electrical conductivity; $\mathrm{TOC}=$ total organic carbon; $\mathrm{CEC}=$ cation exchange capacity; $\mathrm{V}=$ base saturation; Als = aluminum saturation.

In the dendrogram generated by the cluster analysis (Figure 1), the reading is made from right to left, in which the $\mathrm{y}$ axis indicates the distances between the formed groups, and the $\mathrm{x}$ axis represents the groups joined in descending order of similarity. A high dissimilarity indicates that two individuals are distinct from the set. The cluster analysis formed four groups, with Groups I and IV formed from a single soil class (I from Haplustepts; and IV from Calciustolls), while Group II were formed from Haplustepts and Eutrustox, and Group III from Haplustepts, and Usticfluvents. The physical attributes were determinant for the dissimilarity of the horizons between soil classes for Groups I, II, and III, and chemical attributes were determinant for Group IV (Figure 1).

Group I was represented by areas with native forest, where the consolidation of the surface due to absence of soil turning of Haplustepts affected directly the physical attributes WMD, TPd, microporosity, aeration, clay, $\mathrm{AGR}>2 \mathrm{~mm}$, and the consistence limits (PL, LL, PI), agreeing with the results of the correlation matrix (Table 1) and the dendrogram (Figure 2). These results were similar to those of the Haplustepts due to active clay fraction of the soil; different types of clay confer different characteristics of cohesion and adhesion, affecting structural attributes. These properties were affected by the origin material of the Haplustepts, which belong to the Jandaíra formation, conferring them expressive adhesion and cohesion forces. These forces are dependent on the soil moisture, consistency, and aggregation, and affect the structural stability, depending on the clay content and type by the formation of primary aggregates; and the most stable aggregates (secondary aggregates) are dependent on the energy input (SOM) through microbial activity (Brady \& Weil, 2013).

WMD, Dp, $\mathrm{Mg}^{2+}$, volumetric moisture $(\theta), \mathrm{TS}$, and Als were significant for Group II (Figure 2), with predominance of sand fraction in the surface layer, which was more expressive in the Eutrustox. This result is explained by the intense weathering that occurs in this soil class, compared to the others. These correlations are due to the clay fraction, which affects various physical attributes and influences the soil structure. Ghidin et al., (2006) evaluated the correlation between clay fraction and structural properties and reported that the mineral content in the clay fraction is more important to defining the soil structure and porosity than its crystallographic characteristics. Similarly, Vasconcelos et al. (2010) emphasized the contribution of different types of clay to the description of soil physical attributes. 


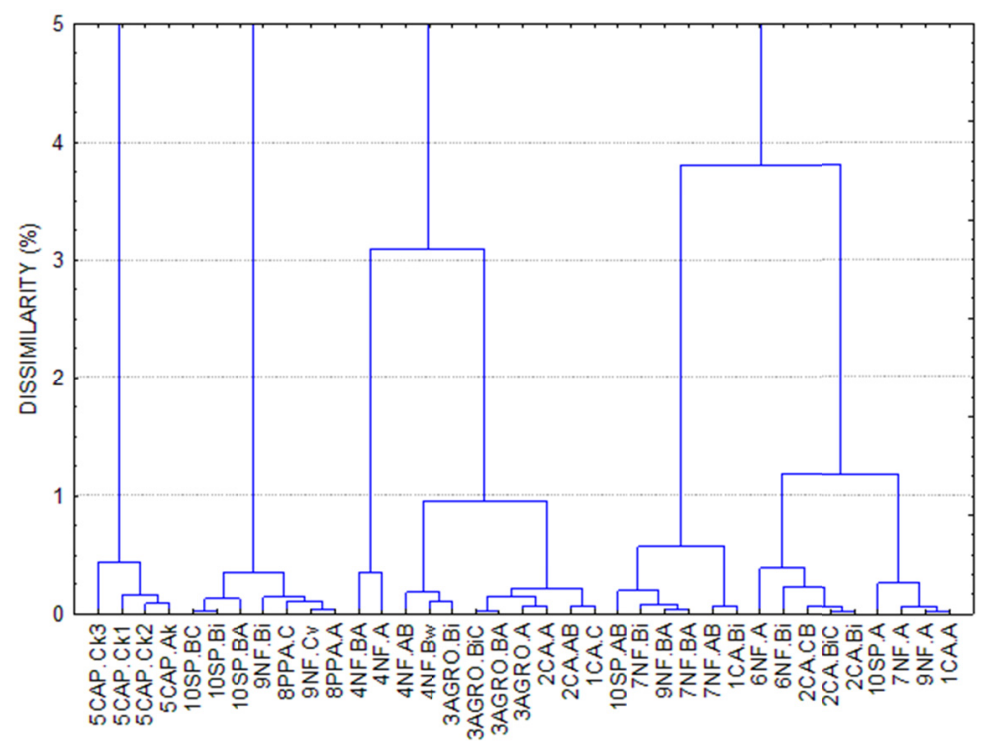

Figure 1. Dendrogram of the distance matrix by the linkage-based clustering

The attributes TPc, Macrop, Silt, $\mathrm{Na}^{+}$, and EC were significant for Group III, especially for the Usticfluvents. It indicates young, not weathered, eutrophic (sum of bases $\geq 50 \%$ ) soils, with masked fertility because of its $\mathrm{Na}^{+}$ contents; the increased EC indicated a high content of soluble salts (Figure 1).

Group IV was differentiated from the others by encompassing only the Calciustolls, and according to the correlation matrix (Table 1 and Figure 2), the chemical attributes $\mathrm{pH}, \mathrm{V}, \mathrm{Ca}^{2+}, \mathrm{T}, \mathrm{TOC}, \mathrm{K}^{+}$, and $\mathrm{P}$ were significant. This indicates young, little weathered soils, with physical limitations regarding drainage due to intrinsic characteristics and location in the landscape (lower levels).

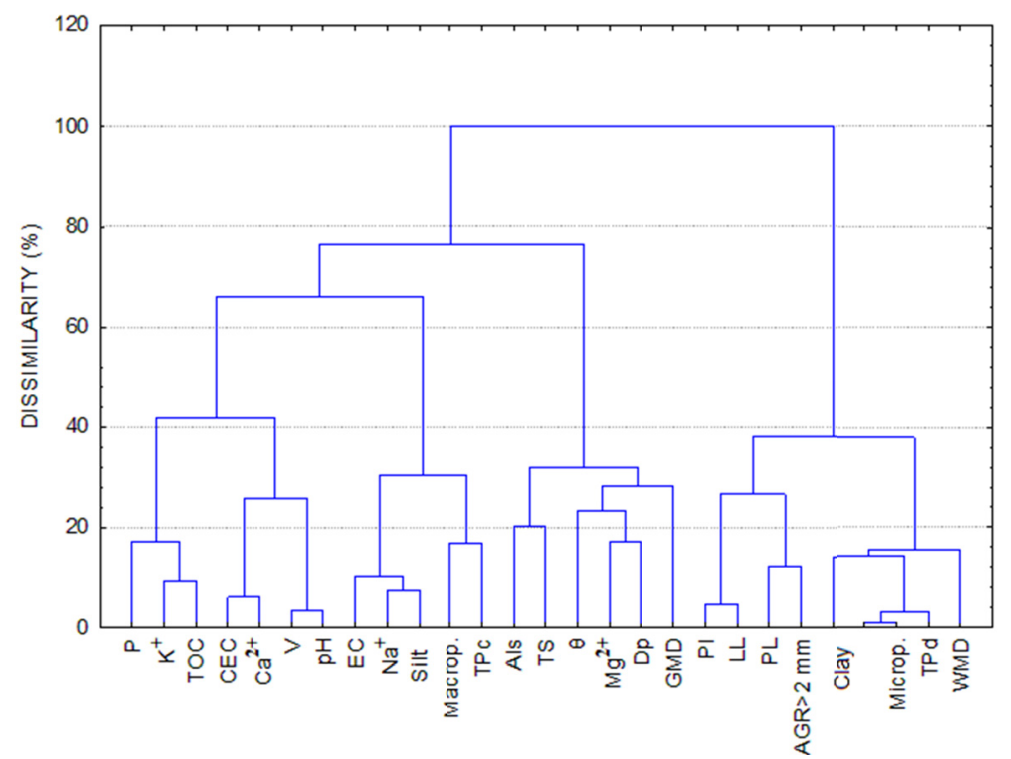

Figure 2. Euclidean distance between variables within the soil groups formed

Table 2 shows the factors extracted from the 27 variables studied, with accumulated proportion from Factor 1 (F1) to Factor (F6), which explained approximately $80 \%$ of the total variance of the results. F1 allowed estimating the influence of expressive variables, with positive factorial loads for the differentiation of the environments, especially clay, $\mathrm{Na}^{+}, \mathrm{Ca}^{2+}$, sum of bases (SB) and $\mathrm{V}$. These attributes varied between classes and environments, which is a consequence of the factors and pedogenic processes that are strongly affected by the 
climatic pattern of the semiarid region in the Northeast region of Brazil and the soil location in the landscape. Factorial analysis showed that most of the variance $(\mathrm{F} 1=26.72 \%)$ were due to interrelations between inorganic fractions (especially clay fraction) and chemical attributes (Tables 1 and 2, and Figures 1 and 2). Similarly, Souza et al. (2018) reported clay, total sand, $\mathrm{Ca}^{2+}, \mathrm{Mg}^{2+}, \mathrm{OM}$, and SB as the variables that contributed the most to discriminate environments.

Macroporosity, microporosity, Dp, $\mathrm{K}^{+}$, and CEC was significant for $\mathrm{F} 2$, presenting positive factorial loads (17.30\%); WMD, geographic mean diameter (GMD) and AGR $>2 \mathrm{~mm}$ was significant for F3, describing $12.39 \%$ of the data of aggregation of soils; and PI, TPc, TS were the most significant $(10.13 \%)$ for F4. The other factors (F5 and F6) were less expressive, presenting lower factorial loads ( $7.39 \%$ and $4.73 \%$, respectively) for the grouped attributes $\theta, \mathrm{pH}, \mathrm{EC}$, and $\mathrm{PL}$, and were affected by $\mathrm{F} 1$ and $\mathrm{F} 2$.

The inorganic fractions (sand, silt, and clay) directly affected the chemical (F1) and structural (F2) attributes; different clay contents were essential to differentiate the environments, explaining $26.72 \%$ of the causes of variance. The sum of the accumulated variances (F1 and F2) explained $44.03 \%$ of the causes of variance, therefore, they were the factors that contributed the most to distinguish the studied environments.

Table 2. Factor axes extracted for soil attributes and their respective factorial loads, eigenvalues, and total and accumulated variances

\begin{tabular}{|c|c|c|c|c|c|c|}
\hline & Factor 1 & Factor 2 & Factor 3 & Factor 4 & Factor 5 & Factor 6 \\
\hline WMD & -0.017 & 0.099 & 0.909 & 0.201 & 0.081 & 0.183 \\
\hline GMD & -0.013 & 0.102 & 0.906 & 0.209 & 0.075 & 0.191 \\
\hline $\mathrm{AGR}>2 \mathrm{~mm}$ & 0.132 & 0.029 & 0.806 & -0.112 & 0.092 & -0.079 \\
\hline LL & 0.332 & -0.055 & 0.408 & 0.321 & 0.073 & 0.504 \\
\hline PL & 0.035 & -0.056 & 0.165 & -0.246 & -0.115 & 0.695 \\
\hline PI & 0.333 & 0.077 & 0.164 & 0.858 & 0.057 & 0.153 \\
\hline TPd & 0.052 & 0.462 & -0.415 & 0.468 & -0.222 & 0.237 \\
\hline TPc & 0.302 & -0.126 & 0.284 & 0.744 & 0.344 & 0.031 \\
\hline Microporosity & -0.321 & -0.649 & -0.257 & -0.455 & 0.148 & -0.080 \\
\hline Macroporosity & 0.220 & 0.848 & -0.004 & 0.028 & -0.087 & 0.038 \\
\hline Total sand & 0.083 & 0.204 & 0.051 & -0.738 & 0.059 & 0.154 \\
\hline Silt & 0.124 & -0.105 & -0.079 & -0.498 & 0.138 & 0.229 \\
\hline Clay & 0.868 & 0.308 & -0.096 & -0.068 & 0.132 & -0.103 \\
\hline $\mathrm{Dp}$ & 0.145 & 0.769 & 0.228 & -0.024 & 0.113 & -0.184 \\
\hline$\theta$ & 0.165 & -0.178 & 0.012 & 0.037 & 0.841 & -0.101 \\
\hline $\mathrm{pH}$ & -0.008 & 0.151 & 0.199 & 0.019 & 0.807 & 0.116 \\
\hline $\mathrm{EC}$ & 0.230 & -0.280 & 0.128 & -0.159 & 0.664 & -0.183 \\
\hline TOC & 0.070 & 0.917 & -0.023 & -0.029 & -0.084 & -0.004 \\
\hline $\mathrm{P}$ & 0.581 & -0.198 & -0.218 & 0.490 & 0.316 & 0.248 \\
\hline $\mathrm{K}^{+}$ & -0.364 & 0.665 & -0.275 & -0.303 & 0.136 & 0.242 \\
\hline $\mathrm{Na}^{+}$ & -0.906 & -0.022 & -0.073 & -0.064 & -0.037 & -0.105 \\
\hline $\mathrm{Ca}^{2+}$ & -0.963 & -0.089 & -0.095 & -0.051 & -0.072 & -0.073 \\
\hline $\mathrm{Mg}^{2+}$ & 0.455 & 0.213 & -0.354 & 0.319 & 0.494 & 0.356 \\
\hline SB & 0.974 & 0.094 & 0.076 & 0.083 & 0.102 & 0.031 \\
\hline CEC & 0.052 & 0.911 & 0.076 & -0.082 & -0.111 & -0.079 \\
\hline V & 0.974 & 0.094 & 0.076 & 0.083 & 0.102 & 0.031 \\
\hline Eigenvalue & 6.949 & 4.499 & 3.222 & 2.633 & 1.923 & 1.230 \\
\hline Total variance $(\%)$ & 26.727 & 17.307 & 12.394 & 10.130 & 7.399 & 4.733 \\
\hline Accumulated variance $(\%)$ & 26.727 & 44.034 & 56.423 & 66.560 & 73.95 & 78.693 \\
\hline
\end{tabular}

Note. Factorial axes rotated by the Varimax method. (2) Factorial loads $\geq 0.65$ were considered significant for interpretation purposes. $\mathrm{WMD}=$ weighted mean diameter; $\mathrm{GMD}=$ geometric mean diameter; AGR $>2 \mathrm{~mm}=$ soil aggregates larger than $2 \mathrm{~mm}$; $\mathrm{LL}=$ liquidity limit; $\mathrm{PL}=$ plasticity limit; $\mathrm{PI}=$ plasticity index; $\mathrm{TPd}=$ total porosity determined; TPc $=$ total porosity calculated; $\mathrm{Dp}=$ particle density; $\theta=$ volumetric moisture; $\mathrm{EC}=$ electrical conductivity; TOC $=$ total organic carbon; $\mathrm{SB}=$ sum of bases; $\mathrm{CEC}=$ cation exchange capacity; $\mathrm{V}=$ base saturation. 
In the correlation circle (Figure 3A), inorganic fractions were not concentrated closely, thus, the studied profiles of the different soils presented variability in texture, showing predominance of variables that more discriminated the environments, denoting the interrelations of each site (Figure 3).

The vectors in the correlation circle represented by $\mathrm{Ca}^{2+}$ and $\mathrm{Mg}^{2+}$, TOC and T, and PTc and PTd indicated a high correlation. Similarly, the location of microporosity in the opposite quadrant to macroporosity indicates negative correlations. Three groups of variables were formed because of the interrelations of clay, SB, V, PTc, Ptd, LL; PI, $\mathrm{Mg}^{2+}, \mathrm{V}, \mathrm{WMD}, \mathrm{GMD}, \mathrm{AGR}>2 \mathrm{~mm}, \mathrm{pH}, \mathrm{EC}, \theta$, and PI.

The variables $\mathrm{Na}^{+}$and $\mathrm{Ca}^{2+}$ showed opposite sign and position in the graph (PTc, Ptd, LL, IP, $\mathrm{Mg}^{2+}, \mathrm{V}, \mathrm{WMD}$, GMD, AGR $>2 \mathrm{~mm}, \mathrm{pH}, \mathrm{EC}, \theta, \mathrm{PI}$ ), indicating high concentrations of these variables, and consequently, low $\mathrm{Na}^{+}$ and $\mathrm{Ca}^{2+}$ contents, in the Eutrustox (Figure $3 \mathrm{~B}$ ). The soil classes presented a eutrophic character $(\mathrm{V} \geq 50 \%)$, including the Eutrustox (Profile 4). This is a local peculiarity, due to the climatic pattern of the semiarid region-low precipitation and high evaporation rate, which delays leaching process of exchangeable bases. Ker (1997) reported that variability in physical, chemical, and mineralogical characteristics of Eutrustox soils determines their eutrophic or dystrophic character depending on the factors and processes of soil formation, giving them a specific character according to the climatic pattern of the region, which influences the chemical weathering.

A cluster was formed (Figure 3B) around the axis F1, correlating positively the variables $\mathrm{P} \mathrm{Mg}^{2+}$, clay, microporosity, and $\theta$, highlighting the profiles $3 \mathrm{AGRO}$ and $6 \mathrm{NF}$ (Haplustepts); and EC, and silt in the profiles $3 \mathrm{AGRO}$ (agroecological area) and 6NF (native forest), with emphasis on the silt fraction, indicating young, low weathered soils.

Regarding the principal component analysis (PCA), the TPd, Dp, macroporosity, TOC, and CEC were correlated positively with the profiles 1CA, 2CA, 3AGRO, 6NF, 7NF, 8PPA, 9MN, and 10SP (Haplustepts); and the profile 5 CAP (Calciustolls) was different from the others regarding these attributes, especially chemical attributes. Therefore, the characterization of this environment was affected by the soil intrinsic characteristics, source material, and location in the landscape (low level).

A

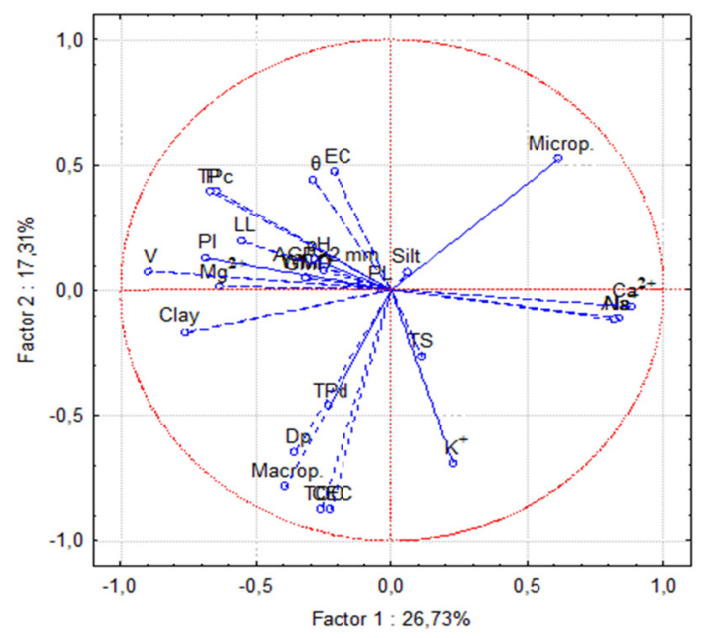

B

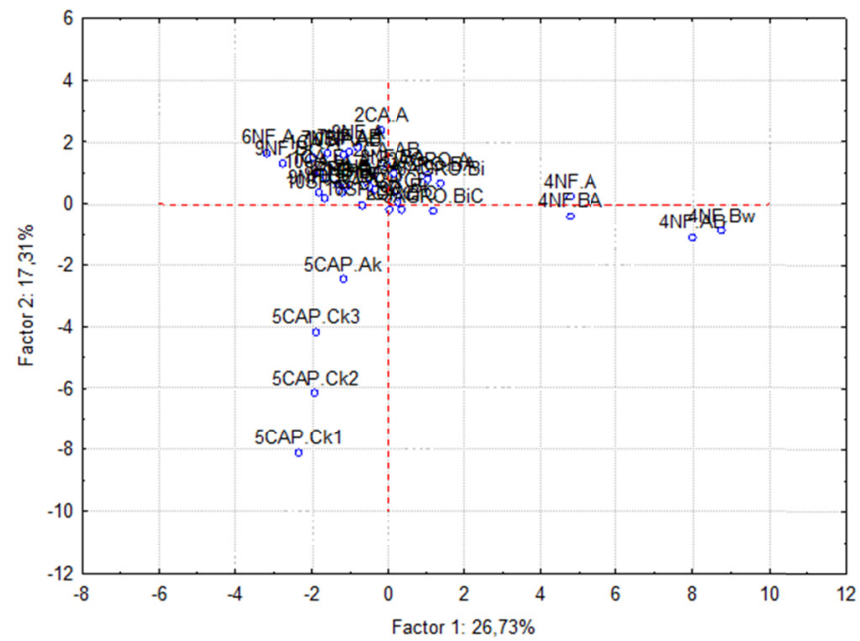

Figure 3. Distribution of the variables in the circle of correlations (A) and distribution of the clouds of points representing the correlation between Factors 1 and 2 (B)

The distribution of the variables in the circle of correlations (Figure 4A) and distribution of the clouds of points (Figure 4B) show the separations between the environments. In F3, the structural variables WMD, GMD, and AGR $>2 \mathrm{~mm}$ were correlated with the aggregation, since these soils have different clay contents and types, acting differently as cementing agents, with clay of colloidal activity having greater stability of aggregates, reducing soil erodibility (Brady \& Weil, 2013). The most significant variables in F4 were PI, TS, and PTc, characterizing different environments by the proportions of inorganic fractions (sand, silt, and clay) of each site. 
A

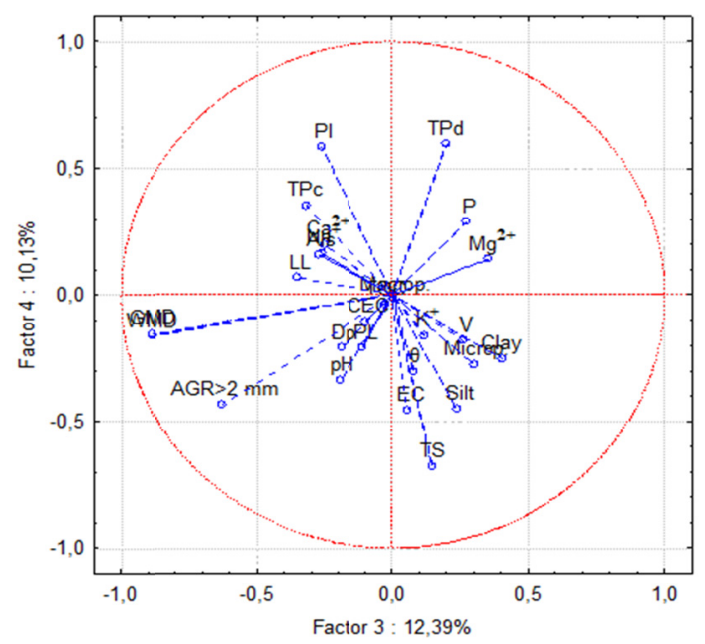

$\mathrm{B}$

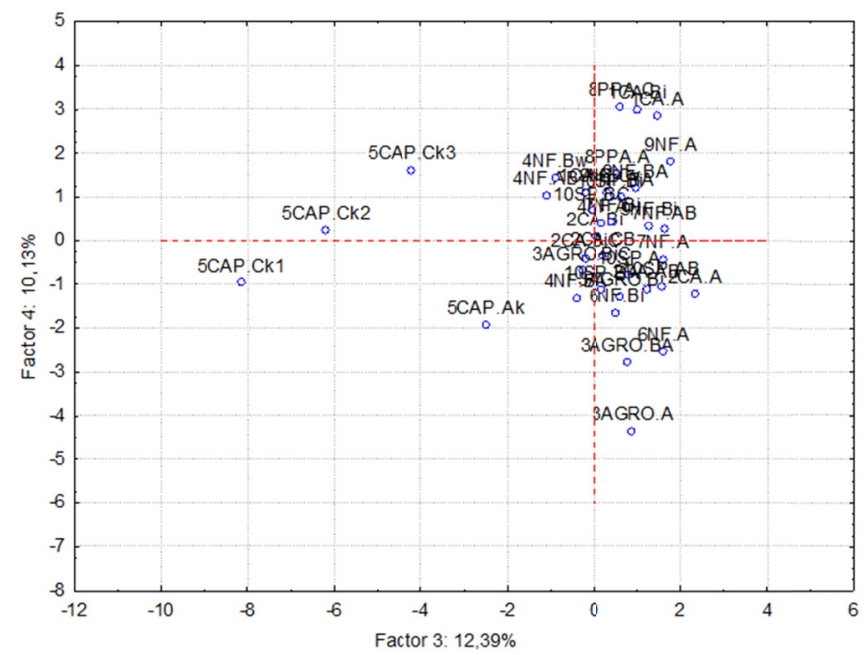

Figure 4. Distribution of the variables in the circle of correlations (A) and distribution of the clouds of points representing the correlation between Factors 3 and 4 (B)

The most discriminant variables for F5 and F6 were $\theta, \mathrm{pH}, \mathrm{EC}$, and PL, which explained $12.12 \%$ of the total variance. The soil $\mathrm{pH}$ was discriminant for Factor 5 for the Haplustepts (6NF) in the A horizon; $\theta$ discriminated the Eutrustox (4NF) in the Bw horizon, by its increased clay fraction in the diagnostic horizon; PL was discriminant for F6 for the Eutrustox (4NF) in the BA horizon; and EC was discriminant for F6 for the Calciustolls (5CAP) (Figure 5).

A

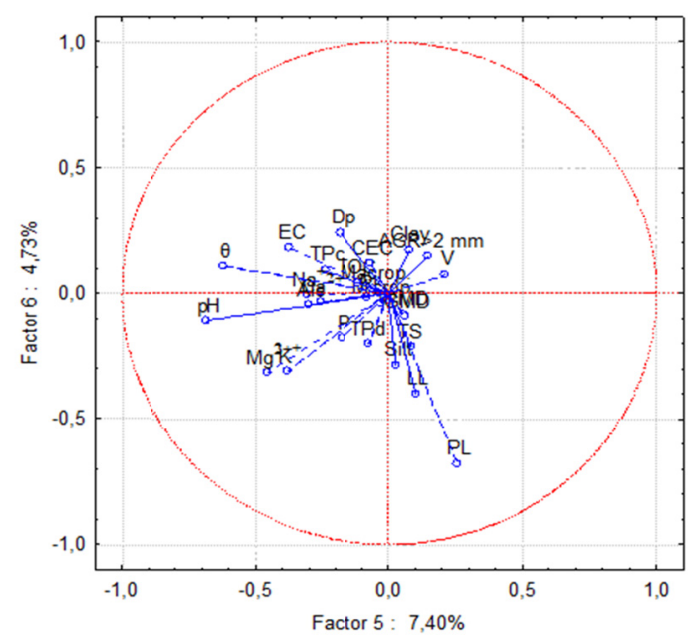

B

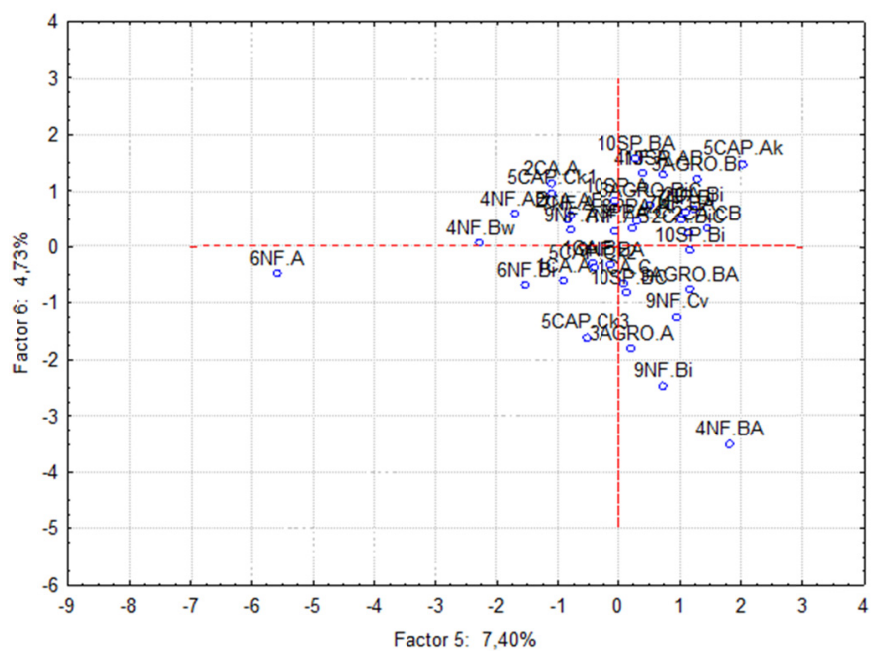

Figure 5. Distribution of the variables in the circle of correlations (A) and distribution of the clouds of points representing the correlation between Factors 5 and 6 (B)

\section{Conclusions}

The physical attributes clay, particle density (Dp), weighted mean diameter (WMD), geometric mean diameter (GMD), soil aggregates smaller than $2 \mathrm{~mm}$ (AGR $>2 \mathrm{~mm}$ ), plasticity index (PI), total sand, volumetric moisture $(\theta)$, and plasticity limit (PL), and the chemical attributes $\mathrm{Na}^{+}, \mathrm{Ca}^{2+}$, sum of bases (SB), base saturation (V), total organic carbon (TOC), $\mathrm{K}^{+}$, cation exchange capacity (CEC), $\mathrm{pH}$, and electrical conductivity (EC) were indicators for the differentiation of the soil classes and land uses. However, clay, $\mathrm{Na}^{+}, \mathrm{Ca}^{2+}, \mathrm{SB}, \mathrm{V}$, microporosity, macroporosity, Dp, EC, TOC, $\mathrm{K}^{+}$, and CEC were the most sensitive variables. 
The chemical attributes $\mathrm{P}, \mathrm{K}^{+}, \mathrm{CEC}, \mathrm{Ca}^{2+}, \mathrm{V}$, and $\mathrm{pH}$ were the most sensitives for the differentiation of the Calciustolls, whereas the physical attributes WMD, GMD, AGR $>2 \mathrm{~mm}$, PI, and PL distinguished the Eutrustox, and the physicochemical attributes $\mathrm{EC}, \mathrm{Na}^{+}$, silt, macroporosity, PTc, aluminum saturation, total sand, $\theta, \mathrm{Mg}^{2+}$, and $\mathrm{Dp}$ distinguished the Haplustepts and the Usticfluvents.

The clay fraction presented interrelation with the chemical attributes (Factor 1), distinguishing the soil classes and land uses depending on their origin material, and local peculiarities.

The soils classes evaluated presented a eutrophic character ( $\mathrm{V} \geq 50 \%$ ), including the Eutrustox, especially due to the $\mathrm{Na}^{+}$and $\mathrm{Ca}^{2+}$, despite its lower contents when compared to the other soil classes, which denotes a local peculiarity because of the climatic pattern of the semi-arid region.

\section{Acknowledgements}

To the Coordination for the Improvement of Higher Education Personnel—CAPES—for the financial support.

\section{References}

Alvares, C. A., Stape, J. L., Sentelhas, P. C., de Moraes, G., Leonardo, J., \& Sparovek, G. (2013). Köppen's climate classification map for Brazil. Meteorologische Zeitschrift, 711-728. https://doi.org/10.1127/09412948/2013/0507

Angelim, L. A. A., Angelim, V. C., \& Nesi, J. R. (2006). Programa Geologia do Brasil-PLGB. Projeto Geologia e Recursos Minerais do Estado do Rio Grande do Norte. Mapa Geológico do Estado do Rio Grande do Norte. Escala. Recife: CPRM/FAPERN.

Brady, N. C., \& Weil, R. R. (2013). Elementos da natureza e propriedades dos solos. Bookman Editora.

Carvalho, A. E. M., Lima, L. A., de Sousa Oliveira, L., \& Costa, M. C. G. (2017). Diagnóstico do uso e conservação do solo em região de reforma agrária no semiárido. Revista Verde de Agroecologia e Desenvolvimento Sustentável, 568-573. https://doi.org/10.18378/rvads.v12i3.4870

Castilho, K. B., Cortez, J. W., Olszevski, N., Salviano, A. M., \& Trindade, M. H. (2017). Análise multivariada da qualidade química de um Latossolo sob sistemas de manejo do solo. Agrarian, 10(36), 162-169. https://doi.org/10.30612/agrarian.v10i36.4179

Forsythe, W. (1975). Manual de laboratorio: Física de suelos (No. IICA-LME 25). IICA, San José (Costa Rica).

Hair, J. F., Black, W. C., Babin, B. J., Anderson, R. E., \& Tatham, R. L. (2009). Análise multivariada de dados. Bookman Editora.

Ghidin, A. A., Melo, V. D. F., Costa Lima, V., \& Jonasson Costa Lima, J. M. (2006). Toposseqüências de latossolos originados de rochas basálticas no Paraná. I-Mineralogia da fração argila. Revista Brasileira de Ciência do Solo, 30(2). https://doi.org/10.1590/S0100-06832006000200011

Kemper, W.D. and Rosenau, R.C. (1986). Aggregate Stability and Size Distribution. Methods of Soil Analysis, Part 1. Physical and Mineralogical Methods (2nd ed.). Agronomy Monograph (Vol. 9, pp. 425-442).

Ker, J. C. (1997). Latossolos do Brasil: Uma Revisão. Geonomos, 5, 17-40. https://doi.org/10.18285/geono mos.v5i1.187

Kiehl, E. J. (1979). Manual de edafologia: Relações solo-planta (p. 262). São Paulo: Ceres.

Leite, J. N. F., Cruz, M. C. P. D., Ferreira, M. E., Andrioli, I., \& Braos, L. B. (2016). Organic and inorganic P forms in soil as affected by cover crops and nitrogen fertilization. Pesquisa Agropecuária Brasileira, 51(11), 1880-1889.

Lepsch, I. F., Espindola, C. R., Vischi Filho, O. J., \& Hernani, L. C. (2015). Manual para levantamento utilitário e classificação de terras no sistema de capacidade de uso. Campinas: SBCS.

Machado Vezzani, F., \& Mielniczuk, J. (2009). Uma visão sobre qualidade do solo. Revista Brasileira de Ciência do Solo, 33(4). https://doi.org/10.1590/S0100-06832009000400001

Machado, V. J., \& de Souza, C. H. E. (2012). Disponibilidade de fósforo em solos com diferentes texturas após aplicação de doses crescentes de fosfato monoamônico de liberação lenta. Bioscience Journal, 28(1).

Marinho, A. C. C. S., Portela, J. C., Silva, E. F., Dias, N. S., Sousa Júnior, F. S., Silva, A. C., Silva, J. F. (2016). Organic matter and physicochemical attributes of a Cambisol under different agricultural uses in a semi-arid region of Brazil. Australian Journal of Crop Science, 10, 32-41. 
Mota, A. J. C., Nonato de Assis Júnior, R., Amaro Filho, J., \& Libardi, P. L. (2008). Algumas propriedades físicas e hídricas de três solos na chapada do Apodi, RN, cultivados com melão. Revista Brasileira de Ciência do Solo, 32(1). https://doi.org/10.1590/S0100-06832008000100006

Pereira, M. G., Loss, A., Beutler, S. J., \& Torres, J. L. R. (2011). Carbono, matéria orgânica leve e fósforo remanescente em diferentes sistemas de manejo do solo. Pesquisa Agropecuária Brasileira, 45(5), 508-514. https://doi.org/10.1590/S0100-204X2010000500010

Perin, A., Silva Santos, R. H., Urquiaga Caballero, S. S., Marinho Guerra, J. G., \& Gusmão, L. A. (2010). Acúmulo e liberação de P, K, Ca e Mg em crotalária e milheto solteiros e consorciados. Revista Ceres, 57(2). https://doi.org/10.1590/S0034-737X2010000200020

Ribeiro, A. C., \& Guimarães, P. T. G. (1999). Recomendações para o uso de corretivos e fertilizantes em Minas Gerais ( $5^{\mathrm{a}}$ aproximação). Comissão de Fertilidade do Solo do Estado de Minas Gerais.

Ribeiro, K. D., Menezes, S. M., de Freitas, M. D. G. B., \& Sampaio, F. D. M. T. (2007). Propriedades físicas do solo, influenciadas pela distribuição de poros, de seis classes de solos da região de Lavras-MG. Ciência e Agrotecnologia, 31(4), 1167-1175. https://doi.org/10.1590/S1413-70542007000400033

Sá Paye, H., Vargas de Mello, J. W., \& Bezerra de Melo, S. (2012). Métodos de análise multivariada no estabelecimento de valores de referência de qualidade para elementos-traço em solos. Revista Brasileira de Ciência do Solo, 36(3). https://doi.org/10.1590/S0100-06832012000300033

Souza, H. S., Tsukamoto Filho, A. D. A., de Souza, É. C., Arriel, D. A. A., \& Medeiros, R. A. (2018). Análise multivariada de atributos químicos e físicos do solo em sistema agroflorestal com teca. Scientia Agraria, 19(1), 87-93.

StatSoft. (2004). Statistica Version 7.0. Retrieved from http://www.statsoft.com

Teixeira, P. C., Donagemma G. K., Wenceslau, A. F., \& Teixeira, G. (2017). Manual de Métodos de Análise de Solo (3rd ed., p. 573). Rio de Janeiro: Embrapa Solos.

Turrión, M. B., López, O., Lafuente, F., Mulas, R., Ruipérez, C., \& Puyo, A. (2007). Soil phosphorus forms as quality indicators of soils under different vegetation covers. Science of the Total Environment, 378(1-2), 195-198. https://doi.org/10.1016/j.scitotenv.2007.01.037

Vasconcelos, R. D., Cantalice, J. R. B., Silva, A. J. N. D., Oliveira, V. D., \& Silva, Y. J. A. B. (2010). Limites de consistência e propriedades químicas de um Latossolo amarelo distrocoeso sob aplicação de diferentes resíduos da cana-de-açúcar. Revista Brasileira de Ciência do Solo, 34(3), 639-648. https://doi.org/10.1590/ S0100-06832010000300005

\section{Copyrights}

Copyright for this article is retained by the author(s), with first publication rights granted to the journal.

This is an open-access article distributed under the terms and conditions of the Creative Commons Attribution license (http://creativecommons.org/licenses/by/4.0/). 